\title{
APPLYING AFFINITY GROUPING STRATEGY THROUGH PROCESS-BASED CLASSIFICATION ESSAY WRITING TO IMPROVE THE STUDENTS' WRITING ABILITIES
}

\author{
Vivi Aulia \\ English Department, STKIP-PGRI Banjarmasin
}

\begin{abstract}
This article is a report of one-cycle Classroom Action Research conducted to the fifth undergraduate English majors in STKIP-PGRI Banjarmasin. This study was conducted to implement the strategy of affinity grouping which became an alternative to solve the students' writing problem of exploring and generating ideas which, in turn, improved their writing abilities. The instruments used for collecting data were field notes, questionnaires, and students' classification essay projects. It was found out that affinity grouping not only improved students' writing abilities but also helped them figure out what topic to write, developed their general ideas, and elaborated satisfying information and sufficient details of their ideas generation.
\end{abstract}

Abstrak: Artikel ini merupakan sebuah laporan satu siklus Penelitian Tindakan Kelas (PTK) yang diimplementasikan kepada mahasiswa semester kelima jurusan Pendidikan Bahasa Inggris di STKIP-PGRI Banjarmasin. Studi ini dilakukan guna mengimplementasikan strategi Affinity Grouping sebagai salah satu alternatif untuk memecahkan permasalahan menulis mahasiswa dalam hal mengekplorasi dan mengembangkan ide, yang selanjutnya dapat meningkatkan kemampuan menulis mereka. Instrumen yang digunakan untuk pengumpulan data adalah catatan lapangan, kuesioner, dan hasil classification essay yang dibuat mahasiswa. Selanjutnya ditemukan bahwa affinity grouping tidak hanya meningkatkan kemampuan mahasiswa dalam menulis, tetapi juga membantu mereka menggambarkan topik yang akan ditulis, mengembangkan ide, dan memperjelas informasi penting serta hal-hal detail terkait ide yang ditulis.

Key words: affinity grouping, students' ideas generation, classification essay

\section{INTRODUCTION}

English is taught as a foreign language in Indonesia and learned after the students master their first and second languages. The recent English curriculum objective is designed to develop students' communicative competence both in oral 
and in written communication. English proficiency is one of the main requirements for those who want to involve themselves in occupational or academic purposes as well as in communication and relationships within and between communities around the world (Sharifian, 2009:1).

In the Indonesian context of English language teaching, competence in writing for students in undergraduate level of English majors particularly is considered as important as competence in other language skills. Writing is not only a tool for communication, but also it serves as a means of learning, thinking, and organizing knowledge or ideas. Moreover, writing is one of four basic language skills that has increased significance for English majors as it represents the main medium they use to do assignments in the different subject areas and answer examination questions. Disciplinary knowledge and understanding are largely exhibited and valued through the medium of writing (Coffin et al, 2003:9).

STKIP-PGRI Banjarmasin is a university located in Banjarmasin has an English department that trains and prepares students to master English and to be professional English teachers. Beginning in the third semester, the students are trained on how to improve their writing abilities. The objective of the course is to give learning experiences and skills to students to be able to write in English (English Department Curriculum of STKIP-PGRI Banjarmasin, 2012). They are trained to write in English through writing activitiy phases, beginning with sentence writing (Writing I), continued with paragraph writing (Writing II), and academic writing including essay writing in the fifth and sixth semester (Writing III and IV).

Further, in the fifth semester, the teaching of writing (Writing III) is focused on how to increase the students' mastery in developing their ideas into essays, how the essay is physically structured in forms of its format and layout as well as on how the words are organized, increase their dictions in writing, and improve their writing abilities particularly in accuracy.

In the context of students' activities in essay writing classes, it was found that students performed worse when they were given a topic. In turn, they also performed worse when they were given some topics to be selected as their writing basis. According to Thomas (2005), it is true that in thinking about the question of whether or not to provide topic options in an essay examination, one must consider how much 
time will be given to students choose the topic. Sometimes, they seemed to have little background knowledge on the provided topics. As a result, they spent about half of the class time only for figuring out what topic to choose and how to generate their ideas.

Writing essay regularly can cause common problems for a student right from the start, such as thinking of a good topic up to searching and providing information about their chosen topics and correct way of citing their references. The basic problem of the students in writing is the lack of background knowledge. This happened in essay writing class that discussed the classification essay. It was also found that the content of students' composition lack of satisfying information and sufficient details of categories considering that the classification essay provides much information to the readers. It indicated that the students' classification essay projects still need to be improved.

Considering that there are some problems happen in essay writing class, it is important to implement a strategy in activating the background knowledge of the topic being written, developing and organizing their ideas, helping them to express and to transfer their ideas easily, developing the detailed information to their ideas, providing them with such strategy that facilitate them to write, making them write smoothly by coming up with their own ideas, and allowing them to be more active in writing activities.

Affinity grouping which is also called as affinity diagramming is a term describing the variety of strategy designed for grouping and understanding information. In particular, affinity grouping provides a good way to organize the idea and identify common themes by showing on how components or concepts of a particular topic are identified and classified to one another through graphic organizer (Barkley et al, 2005:309). In addition, Wilson (2013) states that affinity grouping can be a powerful strategy as brainstorming tool in which students write down their ideas, organize them, and can assist in prioritizing the next steps by identifying where the greatest interest or concern lies. 


\section{Figure 1 The Model of Affinity Grouping/ Diagramming}

Figure 1

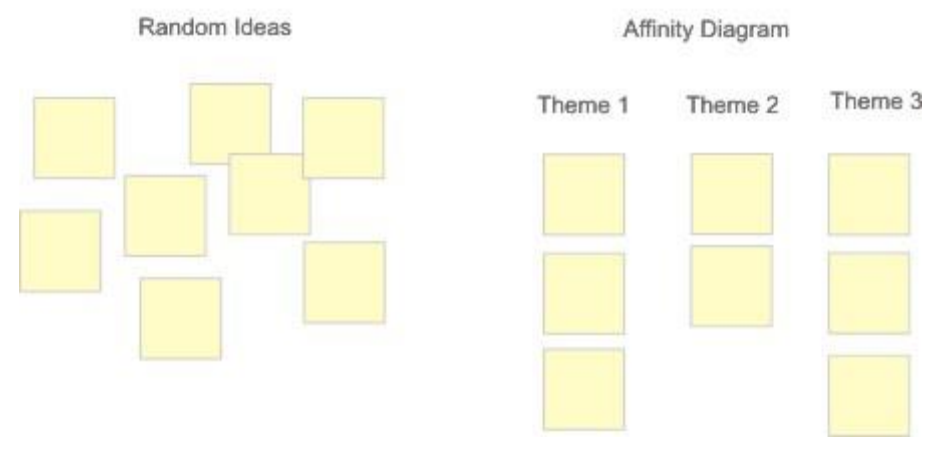

(taken from McClanahan and Wicks, 1994)

In relation to the ways of organizing ideas, affinity grouping might be applied in order to assist students solve their problems. It is widely used and effective way of getting ideas flowing for particular topic or organizing the topic. Furthermore, affinity grouping can be done by the teacher and by the students. Demonstration and illustration of how it works by the teacher is a good way of getting across to students what is involved. Affinity grouping is best done in a group so that it benefits from a collaborative approach to learning. Thus, this strategy ensures that all students in their groups have a chance to participate and build consensus among the group members studying the topic (Weller, 2004:437).

Moreover, the pre-writing activities through affinity grouping can provide students with a clear purpose for writing without which they tend to write aimlessly, fail to schematize, and as a consequence, often miswrite the text. Affinity grouping is also a way to explore the topic which starts with grouping activity. It illustrates the relationship among ideas so as to allow students develop their essays easily.

Representing ideas visually, it goes with saying that this strategy encourages them to want to write. Once the strategy becomes familiar, it helps learners to handle any writing they face in college. In terms of discovering ideas, affinity grouping is worth applying in process-based writing instruction. It allows students to discover what they need to write about the topic. 


\section{METHOD}

This study was conducted in one writing class of 13 students of English majors in STKIP-PGRI Banjarmasin. It was the action research aimed at solving the students' problem in generating the ideas. In order to apply the affinity grouping strategy, adjustment and changes were made when necessary without changing the basic concept and procedure of affinity grouping.

The design of this action research followed the model proposed by Kemmis and McTaggart (1992) comprising of planning, implementing, observing, and reflecting the actions. The preliminary test was carried out to find out the description of students' abilities in writing. This test was conducted by asking them to write free classification essay individually using their own topics. The result of this test showed that the average score of whole students was 70 .

Chronologically, the planning stage dealt with the procedural of affinity grouping strategy in which students were involved in process-based writing activity. It consisted of pre-writing, drafting, revising, editing, and publishing stages. Further, affinity grouping was used to facilitate students in first three stages in which those mainly focus on students' activities in generating, exploring, and developing the idea. The last two stages were not used affinity grouping activity since they focused only on polishing and producing final draft of their essays. It was planned that students created five paragraphs of classification essay comprising of an introductory paragraph, three developmental paragraphs, and a concluding paragraph.

Next, the implementing activity deals with the instructional process based on the plan. In this stage, the lecturer involved an observer assisting from the beginning up to the end of the study. The observer had responsibilities to see, to observe, to make notes relating to lecturer and students' activities while implementing the strategy.

The observing activity section was conducted simultaneously with the implementation. In this activity, both qualitative and quantitative data were collected. The qualitative data were obtained by utilizing field notes and distributing questionnaire to see students' reflection and personal appreciation on the implementation of strategy while the quantitative one were taken from students' final classification essay projects. Moreover, the criteria of success were decided in 
this stage. Quantitatively, the criteria of success was overall students could achieve average score of 70 due to the result of preliminary test. Meanwhile, qualitatively, affinity grouping was considered helpful to the students if the result of field notes and questionnaire showed at least $75 \%$ or 9 students of 12 students were able to apply the strategy to their writing and delivered positive comments toward its implementation.

As a reflection process, both quantitative and qualitative data were analyzed and incorporated to see the implementation of strategy. Drawing conclusion were carried out then to decide whether the action was successful or not.

\section{FINDINGS}

\section{Pre-writing activity}

The lecturer demonstrated the way of creating affinity grouping, categorizing ideas into grouping, paragraphing, etc. Moreover, the lecturer informed them that they were going to implement process-based writing using affinity grouping. Several students showed their enthusiasms by asking the questions to the lecturer as follows:

Student A : "I have difficulties in generating the topic. How can I complete the overall of process writing since the problem comes from the beginning to write?".

Student B : "We have practiced about writing process in last semester in paragraph writing. However, it took a long time. How can affinity grouping contribute useful way to our writing since making affinity grouping itself also needs a long time?"

The lecturer further explained that they were going to implement affinity grouping guided by the lecturer. This would help them easier to use this strategy. The implementing activity was started in this stage in which the lecturer distributed slips of sticky notes. Then, the lecturer gave them a topic to be discussed (Transportation), placed them into groups of three, and asked all members of the group to silently brainstorm ideas concerning the topic. They must write one introduced topic on individual sticky notes and wrote at least three supporting information of the topic. They must use a new sticky note for each new detail and write in phrases to facilitate the brainstorming process. 
However, a problem occured in this step. Many students felt confused to begin and to find out their three supporting information. The lecturer assumed that this happened because most of them still could not figure out the topics. Since the goal of this study is to make the students able to generate and to explore the idea, the lecturer guided them to write any kinds of information based on their prior knowledge.

Afterward, one group member should collect the sticky notes, mixed them up, and spread them out on the table. Each group member, in turn, should place each note randomly on the whiteboard and do this process until all the sticky notes have been grouped together into categories. The lecturer responded to all ideas from others. Finally, once a consensus was reached regarding details listed and categories, the lecturer asked the groups to create a title or heading for each grouping that best describe the theme of each group of items. Feedback was given to the class after accomplishing this stage.

Figure 2. The Result of Affinity Grouping After Discussion

\section{$\underline{\text { Transportation }}$}

People have a big need of mobility in the modern era

People need to travel everywhere and around the world

Human invented vehicles and possible means of transportation

Category A

Land transportation

\section{Detail 1}

The most common and cheap transportation
Category B

Water transportation

\section{Detail 1}

Long long ago,

Christopher Columbus used ship to found
Category C

Air transportation

\section{Detail 1}

It is the fastest and expensive transportation 
Detail 2

Cars are produced by manufacturers with many different types

\section{Detail 3}

There are lots of car choices out there and it is easier and worldwide used by people.
Detail 2

It is possible to be used for going to other island or somewhere across the sea

Detail 3

It can be used to load things that will be sent to another place in lower price
Detail 2

Almost every distance and destination are possible for us to reach

\section{Detail 3}

It does not need much time to travel around the world

Finally, field notes reported that about 9 students of 12 students were considered to be able to cooperate in group collecting sufficient information through affinity grouping. Three students left were considered unable to provide any detailed information in their affinity groups.

\section{Drafting activity}

The students have arranged and accomplished affinity grouping in group a day in advance. In the following meeting, the students worked individually in drafting activity. This stage focused on giving them chance to produce their first drafts based on the grouping as a guide to support their drafts. The lecturer instructed them to start producing their first drafts by writing thesis statement of their essays based on the topic. The lecturer then asked them to continue writing an introductory paragraph, three developmental paragraphs, and a concluding paragraph of their essays based on information stated in affinity group. The sample of students' first drafts can be seen in the following examples:

In modern and globalization era, people around the world believe that travelling is a part of their lifes. People have a big need of mobility. Almost all families over the world travel anywhere and it is possible to travel around the world. There are three kinds of transportation that facilitate people around the world to travel.

(a first draft paragraph created by Student A) 
The other means of transportation is the air transportation. Long ago, Christopher Columbus use it to find America. It is the expensive transportation and we must go to airport to travel by using it. It makes almost every distance is possible for us to reach, such as: the holiday trip to Singapore, hajj trip to Saudi Arabia, etc.

(a first draft paragraph created by Student B)

From the samples above, the students tried to actively convert collected information provided in affinity group into their first drafts without considering the errors made by them in terms of grammar and sentence structure. According to the field notes recorded, the students seemed to start writing without hesitation. They did it without spending much time to start writing. Furthermore, based on the students' writing activities, all the students were considered to be able to arrange their essays based on information stated in affinity group.

\section{Revising activity}

This revising activity allowed students to rethink and rewrite the first drafts, reconstructed the content of grouping (if necessary), then produced the second drafts. The students had to follow the information stated in affinity group to make a revision of their first drafts. The step were not really different from the previous stage, however; the students revised their first drafts using peer review rubric (revision guideline rubric). The students exchanged their first drafts each other. Everybody corrected their classmates' works using thus rubric.

Peer review is an interactive process of proofreading and commenting on a classmates' writing. It consists of some questions about specific elements that the lecturer hopes to find in their essays -a strong thesis statement, clear topic sentences, clear kinds of category, specific supporting details of each category, coherence, an effective conclusion, and so on-. By answering the worksheet questions thoughtfully, the students can learn to recognize the strengths and weaknesses in their rhetorical skills as well as to spot recurring errors in content and organization. The samples are presented as follows:

From those explanation above, we can conclude that we are the lucky generation. We live in modern era that has many kinds of transportation. We can go anywhere we want witht many choices of transportation based on our budget.

(a first draft paragraph created by Student E) 
- $\quad$ The conclusion is less of strong restatement of the thesis

- You need to add your comment or your suggestion to the reader

- What do you mean : we are the lucky generation. What happen with lucky generation? I think it needs to be explained clearly why do we are the lucky generation connecting with transportation itself. (Review given by Student F)

According to field notes recorded, there were 11 students could do peer review activity. They could make corrections and give suggestions to their classmates' works. Some of them delivered positive comments and found something good to say, but there were also the students who delivered negative comments to their classmates' works. The lecturer formally announced to them that in peer review activities, the writer might not always agree with their classmates' comments. As a result, the lecturer asked them to regard their different opinions, not to argue and hurt their classmates' feelings.

\section{Editing and Publishing Activities}

Editing activity allowed students to put the piece of writing into its final form by correcting the grammar, punctuations, and mechanics components. The lecturer asked the students to exchange their second drafts with peers' one more time. The student's each draft would be edited by the peer in terms of grammatical mistakes or errors, the use of punctuation,diction, and other mechanical errors. The sample of students' editing are presented as follows:

The second kinds of transportation is water transportation. Long long ago, Christoher Columbus use it to find America. The water transportation makes us possible to go to other island or across the sea. When we travel, we can choose any water transportation, such as: ship, raft, boat, and others. Water transportation provides place to load things that will be sent to another place with lower price. ( a second draft created by Student G)

The second means of transportation is water transportation. Long long ago, Christopher Columbus used ship to go around the world and find out America. Water transportation makes us possible to go to other islands or somewhere across the sea or river. We can choose anykinds water transportation based on our needs, such as: ship, raft, boat, etc. Besides, it can be used to load things that will be sent to other places with lower price. (edited by Student $\mathrm{H}$ ) 
Based on field notes recorded, the students without the lecturer's instruction began re-writing their second drafts that have been edited to become their final essay projects. Finally, in the publishing stage, the lecturer asked them to publish their works by typing their final essays at home and provide relevant, attractive, and interesting images as illustration of their writing.

\section{Result of Students' Classification Essay Projects}

The results of students' final classification essay projects were analyzed through five writing components: format, punctuations and mechanics, content, organization, and grammar and sentence structure. Both the lecturer and the observer assessed and evaluated the students' works. The description of the results of students' final classification essay projects are presented in Table 1.

Table 1. The Results of Students' Final Classification Essay Projects.

\begin{tabular}{|c|c|c|c|c|}
\hline \multirow{3}{*}{$\begin{array}{l}\text { Number of } \\
\text { students }\end{array}$} & \multicolumn{2}{|c|}{$\begin{array}{c}\text { Rater I } \\
\text { (the lecturer }\end{array}$} & \multicolumn{2}{|c|}{$\begin{array}{c}\text { Rater II } \\
\text { (the observer) }\end{array}$} \\
\hline & $\begin{array}{l}9 \text { students } \\
(75 \%) \\
\text { achieved } \\
\text { score } 70-75\end{array}$ & Good level & $\begin{array}{c}8 \text { students } \\
(67 \%) \\
\text { achieved score } \\
70-75\end{array}$ & Good level \\
\hline & $\begin{array}{l}3 \text { students } \\
(25 \%) \\
\text { achieved } \\
\text { score } 76-80\end{array}$ & $\begin{array}{c}\text { Very Good } \\
\text { level }\end{array}$ & $\begin{array}{c}4 \text { students } \\
(33 \%) \\
\text { achieved score } \\
76-80\end{array}$ & $\begin{array}{c}\text { Very Good } \\
\text { level }\end{array}$ \\
\hline $\begin{array}{c}\text { Mean score } \\
\text { of overall } \\
\text { students }\end{array}$ & \multicolumn{2}{|c|}{72.4} & \multicolumn{2}{|c|}{73.6} \\
\hline $\begin{array}{l}\text { Final mean } \\
\text { score }\end{array}$ & \\
\hline
\end{tabular}

From the results of students' final classification essay projects above, it was found that mean score for whole class was 73 . Since the result of preliminary test was 70 , it could be concluded that the students' average scores increase from 70 to 73. In other words, there was improvement of students' achievement after implementing affinity grouping strategy. 


\section{Results of Students' Responses on the Implementation of Affinity Grouping}

As mentioned in previous section that the data related to students' responses on the implementation of affinity grouping were obtained by distributing questionnaire. The result of questionnaire showed that $80 \%$ or 10 students had positive personal judgment toward its implementation. They stated that they felt comfortable, felt that it was easy to implement, and considered to use it in their next writing activities.

Based on positive personal views given by students, it indicated that the use of affinity grouping in classification essays writing was well-done. By implementing this strategy through process-based writing, there was positive impact to the students' achievement in writing.

\section{DISCUSSIONS}

Based on the findings, it is acknowledged that affinity grouping strategy successfully improve the ability of students in writing classification essay. The use of affinity grouping facilitates them in gathering information related to the topic being discussed easier. Affinity grouping shows its existence mainly in the pre-writing stage, drafting stage, and revising stage.

In general, beginning to write is apparently most of students' problem. One of the solutions to this problem is the students should be guided in carrying out some activities which are usually called pre-writing activities. It is applied before coming to the actual writing to help them produce their ideas on a certain topic. According to Christenson (2002), pre-writing involves everything the writer does before beginning the actual task of writing, including activating background knowledge, generating ideas, and making plans for approaching the writing tasks. For this purpose, brainstorming activity is needed.

For exploring and generating the idea, the lecturer uses brainstorming techniques since this is considered as the easiest invention method. In this technique, the students implement affinity grouping in which they create diagram relationship to show the classification of gathered information through grouping activity. This is used to finding out and collecting information so that choices of category of the discussed topic would be detailed and informative. 
Concerning to the use of affinity grouping strategy, it gives students fun activities; especially in classifying and grouping the topic. This help them reducing the problems in exploring ideas in writing. It also facilitates students' learning that make the activity more interesting. Meanwhile, the students enjoyed some activities and they were encouraged to be involved in activities during the implementation of strategy. Besides, the affinity grouping can stimulate their inspiration, to help them to get involved, and to get information on what they should write (Barkley et al, 2005: 317)

Dealing with affinity grouping strategy activities, it is important to consider the students' activities in group work. Through group work, the students can share their ideas and opinion to get comments and feedbacks from their peers in the group. Furthermore, group work creates a learning community among the students in which they could work together and help one another. According to Harmer (2003:117), the use of group work can increase the amount of learner talk and it promotes learners autonomy by allowing students to make their own decisions in the group without being told what to do by the teacher. In line with this, affinity grouping strategy has led students to reach consensus in determining an appropriate model of grouping and its information as their writing basis.

Referring to all information, the researcher synthesized that affinity grouping is one of alternative worth applying in teaching of writing. The students need to be trained with a real writing situation in which they need to practise the writing process, such as generating and organizing ideas as pre-writing, and continue drafting, revising, editing, and publishing. Nevertheless, the English teacher should consider that affinity grouping would be best applied to the intermediate level of education, such as junior high school in which they learn to write short paragraph. It is also can be applied in higher level of education, such as senior high school to university level due to consideration that they can work independently. In other hand, affinity grouping would not be appropriate to be applied to lower levels, such as elementary school students . In the EFL settings, grouping and collecting information activities would be impossibly done due to its complicatedness for this level.

Out of the strengths of affinity grouping strategy, there is a technical weakness on its implementation. It is related with the students' ideas generation in 
affinity group. The students tend to write unrelated information within the topic when they create information in their sticky notes. On the other hand, the lecturer expects they could generate much detailed information. Although affinity grouping is helpful in providing categories and detail of categories for students' writing organizations, it is inadequate to ask them organizing the idea only. It is better to modify the model of affinity group by dividing the group into sub details for certain category. For instance, one major detail category of kinds of transportation can be divided into some sub details, such as: the first means of transportation is land transportation. There are two types of land transportation; machine transportation and animal transportation. This modification will help students elaborate their ideas more specific.

\section{CONCLUSIONS}

In summary, affinity grouping strategy is effective to increase the students' writing abilities. The results of data analysis shows that this strategy is successful to improve students' abilities in writing classification essays. The success is shown by the achievement of two criteria of success. Qualitative criterion deals with results of students' classification essay projects, while quantitative one deals with their personal views toward the implementation of strategy.

Further, the students' improvement is indicated by their essay projects' achievement. There are $75 \%$ or 9 students achieve $70-75$ and the last $25 \%$ or 3 students achieve 76-80. At average, the students' writing scores achieve 73. Since the criteria of success is overall students achieve minimum score 73 , it can be concluded that the implementation of strategy is successful. Furthermore, the result of questionnaire also shows that $80 \%$ or 10 students have positive personal judgment toward the implementation of strategy, feel comfortable, feel that affinity grouping is easy to implement, and consider to use it in the next writing activities.

The study concludes that the implementation of affinity grouping strategy is effective and successful to improve the students' abilities in writing abilities, particularly in terms of gathering ideas for the target topic and its implementation gets positive personal judgments from the students. 
Affinity grouping is applicable for process-based writing. However, it is possibly attached to product writing approach as well as its main concern is on the content and organization. The number of affinity group can be expanded accordingly. In some conditions, the number of its group inhibit the students to collect much information.

Finally, the researcher suggests potential areas for further research applying affinity grouping to other types of essays, such as: comparison and contrast, cause and effect, argumentative, process analysis, descriptive, example essays, etc. Affinity grouping can also be applied in other fields of discipline which require many detailed information which cannot be simply found through writing directly and need brainstorming activity in order to organize adequate information.

\section{REFERENCES}

Barkley, E.E, Cross, K.P, and Major, C.H. 2005. Collaborative Learning Technique: A Handbook for College Faculty. San Fransisco: Jossey-Bass.

Christenson, T.A. 2002. Supporting Struggling Writers in the Elementary Classroom. New York: The International Reading Association.

Coffin, C., Curry, M.J., Goodman, S., Hewings, A., Lillis T.M., and Swann, J. 2003. Teaching Academic Writing. Routledge: New York.

Harmer, J. 2003. The Practice of English Language Teaching. New York: Longman.

Hasil Lokakarya Silabus. 2012. Banjarmasin: STKIP-PGRI Banjarmasin

Kemmis, S. and McTaggart, R. 1992. The Action Research Planner. 3rd ed. Geelong: Deakin University Press.

McClanahan, E. and Wicks, C. 1994. Future Force: Kids That Want To, Can, and Do!. Glendale: Griffin Publishing.

Sharifian, F. 2009. English as an International Language: Perspectives and Pedagogical Issues. Bristol: Multilingual Matters.

Thomas, P.L. 2005. Teaching Writing Primer. New York: Peter Lang.

Weller, L.D. 2004. Quality Middle School Leadership: Eleven Central Skills Areas. Georgia: R\&L Education.

Wilson, C. 2013. Brainstorming and Beyond: A User-Centered Design Method. Waltham: Morgan Kaufmann. 



